\title{
PREVALENCE OF DRUG ABUSE AMONG DRIVERS IN MINIA GOVERNORATE
}

\author{
Rehab Hosni Abdel Kareem and Dalia Mohamed Ali* \\ Forensic Medicine \& Toxicology Department, Faculty of Medicine, Minia University, \\ Egypt
}

\begin{abstract}
Background: In Egypt, drug abuse is one of the dangerous problems that threaten the young adults and worry the government. One of the most essential points for drug abusers are those dealing with the transportation and driving on the road because substance abuse increases the possibility of death after road accidents. Subjects \& methods: The study was conducted in Minia Governorate in order to determine the prevalence of drug abuse in urine samples of drivers. The screening test was done with the co-operation of ministry and ministry of interior. The study was conducted in Minia Governorate from $6^{\text {th }}$ September 2014 till $5^{\text {th }}$ February 2015 on 3338 male drivers aged (16-70) years old. Results: The test was positive in 473 drivers (14.2\%). The highest percentage of drug abuse was observed among age group (18-30) years old. The prevalence of tramadol was $7.2 \%$, Tetrahydrocannabinol (THC) $3.6 \%$, opium $0.15 \%$, benzodiazepines $0.03 \%$, combined tramadol and THC $2.9 \%$, tramadol and opium $0.1 \%$, tramadol and benzodiazepines $0.03 \%$, combined tramadol, THC and opium $0.2 \%$. According to vehicle type; taxi and microbus drivers had the highest percentage of drug abuse followed by private cars then truck drivers. There was a decrease in the number of positive cases among the period of study from September till February. Conclusion: The highest percentage of drug abuse was among age group (18-30) years old. Tramadol was the most common drug of abuse among drivers in Minia Governorate.

Keywords: drug abuse, tramadol, Tetrahydrocannabinol (THC), benzodiazepines,

Minia
\end{abstract}




\section{INTRODUCTION}

Drug abuse or substance abuse, is the use of a drug in a harmful dose or method that injured them (Nutt et al., 2010). These drugs such as: cannabis, opioids, barbiturates, benzodiazepines, and cocaine. The prevalence of drug abuse has increased all over the world last years (Ekpenyong, 2012).

In Egypt, drug abuse is one of the dangerous problems that threaten the young adults and worry the government; because it results in serious complications such as decreased production at work and awful social adaptation (Smook et al., 2014). Conversely, epidemiological data of drug abuse are still insufficient (El-Sawy et al., 2010).

One of the most essential points for drug abusers are those dealing with the transportation and driving on the road. Lillsunde et al., (2012) has reported that substance abuse increases the possibility of death after road accidents. Drug abuse alters the brain functions which is necessary for harmless driving (KenntnerMabiala et al., 2015). Their effects are variable according to the taken dose, the mechanism of action, single or combined drugs, and also the epidemiological pattern of the drug which is different among areas and among classes of drivers. The most common substances abused in Egypt are marijuana and opioids (Loffredo et al., 2015).

Drug abuse alters the psychomotor skills and therefore, increasing the possibility of the motor vehicle crash (Asbridge, 2014). Moreover, use of recreational drugs spread among drivers (Calafat et al., 2009). Many drivers, especially of truck and microbus, believe that those drugs improve their performance and decrease their fatigue (El-Gendy et al., 2015).

Traffic accidents are considered one of the common causes of death all around the world (Andrade and Mello-Jorge, 2016). Road accidents not only cause death but also may lead to permanent infirmities and 
psychological upset for the drivers, passengers and others on the road (El-Akabawi, 2001). World Health Organization (WHO) has reported that 1.25 million deaths per year all over the world are due to road accidents and about $90 \%$ of deaths are in low and middle income countries (World Health Organization, 2015). It further reported that Egypt is one of the top ten countries for the incidence of road deaths. There are about 12 thousands deaths on the road every year. It is considered one of the uppermost rates in the Eastern Mediterranean area (World Health Organization, 2013).

Evaluation of drivers' performance is essential to create strong strategies for road safety. Verstraete and Legrand (2014) have reported that there are two studies to evaluate drivers of substance abuse: epidemiological studies: which are concerned with the incidence of drugs among different classes of drivers, such as roadside surveys and responsibility analyses.
Experimental studies: which are concerned with evaluation of the drivers by laboratory performance tests.

In developing countries, epidemiological data of drug abuse are inadequate due to defective screening programs (Calafat et al., 2009). While, in Europe and North America, the epidemiological studies involved wide range of populations (McCree et al., 2010). Hence, it is compulsory to estimate the incidence of driving under the influence of drugs to assess the safety of road traffic and evaluate the size of the problem in Egypt. The aim of this study is to determine the prevalence of drug abuse in the urine samples of drivers in Minia Governorate and its relation to age, type of vehicle and seasonal variation, if present.

\section{SUBJECTS AND METHODS}

The study was conducted between the $6^{\text {th }}$ of September, 2014 to the $5^{\text {th }}$ of February, 2015 in Minia Governorate at Elkerdahy Police 
station and Minia Psychiatric Hospital and Addiction, New Minia city. Three thousand and three hundred thirty eight male drivers aged (16-70) years old were included in this study.

\section{Ethics}

Ethical clearance was approved for the study by the Ethical Committee of Faculty of Medicine - Minia University, Egypt. In addition, written permissions were obtained from Ministry of Interior and Ministry of Health.

\section{Procedure:}

1- A collection sheet record: age, type of vehicle and seasonal variation

2- Urine samples of drivers were collected in a room (in the police station) without a sink, water flush toilet, detergents, or other potential adulterants. Urine specimens were screened for amphetamine, barbiturates, benzodiazepines, cocaine, THC, opium and Tramadol using multi-drugs one step test.

The multi-drugs one step test panel (urine) is immunoassay test used for qualitative detection of drugs and/or their metabolites. They are rapid urine screening test based on the principle of competitive binding and was obtained from Abon Biopharm Hangzhou Co. Ltd. (China).

3- Further test was done by Viva$\mathrm{Jr}^{\circledR}$ system with Enzyme multiplied immunoassay technique (EMIT). It was the available test at the ministry of health because it was not allowed to take the samples out of the ministry for further analysis according to the instructions of ministry of interior.

\section{Statistical analysis}

The collected data were coded, tabulated and statistically analyzed using Statistical Package for Social Sciences (SPSS for Windows, version 20). Descriptive statistics were done for parametric quantitative data by means, standard deviation, and minimum and maximum of the range, while they were done for categorical data by number and percentage. 
Analyses were done for qualitative data using Chi square test. The level of significance was taken at $(P<$ $0.05)$.

\section{RESULTS}

The test was positive in 473 drivers (14.2\%). According to the vehicle type; taxi and microbus drivers had the highest percentage of cases $(72.4 \%)$ followed by private cars then truck drivers. The highest percentage of cases was observed among age group (18-30) years old. (Tabe 1)

Table 2 revealed that the highest percentage of cases was observed in December (26.2\%). Tramadol showed the highest percentage of positive cases followed by THC then morphine and finally benzodiazepine.

The highest percentage of drug abuse of single drug was higher than the combined drugs. Combined tramadol and THC showed the higher percentage $(2.9 \%)$ than other combinations. (Table 3)

Table 4 showed a significant difference among the age group of tramadol and THC with the highest percentage among the age group (1830) years old and an insignificant difference among the age group of morphine and benzodiazepine.

There was no significant difference among drivers of different types of vehicle in relation to drug abuse. (Table 5) There was a decrease in the number of positive cases among the period of study from September till February. (Table 6) 
Table 1: Descriptive statistics of age and vehicle type

\begin{tabular}{|l|l|}
\hline & $\begin{array}{l}\text { Descriptive statistics } \\
(\mathbf{n}=\mathbf{3 3 3 8})\end{array}$ \\
\hline $\begin{array}{l}\text { Age } \\
\text { Range }\end{array}$ & $(16-70)$ \\
Mean \pm SD & $34.02 \pm 10.13$ \\
\hline $\begin{array}{l}\text { Age groups: } \\
\text { <18 }\end{array}$ & $17(0.5 \%)$ \\
$\mathbf{1 8 - 3 0}$ & $1262(37.8 \%)$ \\
$\mathbf{3 0 - 4 0}$ & $1218(36.5 \%)$ \\
$\mathbf{4 0 - 5 0}$ & $580(17.4 \%)$ \\
$>\mathbf{5 0}$ & $261(7.8 \%)$ \\
\hline $\begin{array}{l}\text { Vehicle type: } \\
\text { Private car } \\
\text { Taxi \& microbus }\end{array}$ & $2416(72.4 \%)$ \\
Truck & $363(10.9 \%)$ \\
\hline Test: & $559(16.7 \%)$ \\
-ve & $2856(85.8 \%)$ \\
+ve & $473(14.2 \%)$ \\
\hline
\end{tabular}


Table2: Descriptive statistics of cases per month and number of positive cases for each drug

\begin{tabular}{|c|c|}
\hline & $\begin{array}{l}\text { Descriptive statistics } \\
(\mathrm{n}=3338)\end{array}$ \\
\hline \multicolumn{2}{|l|}{ Cases per month: } \\
\hline September. & $342(10.2 \%)$ \\
\hline October. & $490(14.7 \%)$ \\
\hline November. & $721(21.6 \%)$ \\
\hline December. & $874(26.2 \%)$ \\
\hline January. & $805(24.1 \%)$ \\
\hline February. & $106(3.2 \%)$ \\
\hline \multicolumn{2}{|l|}{ Tramadol: } \\
\hline -ve & $2991(89.6 \%)$ \\
\hline$+\mathrm{ve}$ & $347(10.4 \%)$ \\
\hline \multicolumn{2}{|l|}{ THC: } \\
\hline -ve & $3116(93.3 \%)$ \\
\hline$+\mathrm{ve}$ & $222(6.7 \%)$ \\
\hline \multicolumn{2}{|l|}{ Morphine: } \\
\hline -ve & $3324(99.6 \%)$ \\
\hline$+v e$ & $14(0.4 \%)$ \\
\hline \multicolumn{2}{|l|}{ Benzo: } \\
\hline -ve & $3336(99.9 \%)$ \\
\hline$+\mathrm{ve}$ & $2(0.06 \%)$ \\
\hline
\end{tabular}


Table3: Descriptive statistics of drugs alone and in combination

\begin{tabular}{|l|l|}
\hline & $\begin{array}{l}\text { Descriptive statistics } \\
(\mathbf{n = 3 3 3 8})\end{array}$ \\
\hline Number of drug: & $2865(85.8 \%)$ \\
No drug. & $367(11 \%)$ \\
One drug. & $100(3 \%)$ \\
Two drug. & $6(0.2 \%)$ \\
Three drug. & $96(2.9 \%)$ \\
\hline Drug combinations: & $3(0.1 \%)$ \\
Tramadol \& THC. & $1(0.03 \%)$ \\
Tramadol \& Morphine. & $6(0.2 \%)$ \\
Tramadol \& Benzo. & \\
Tramadol \& THC \& morphine. & $241(7.2 \%)$ \\
\hline Drug alone: & $120(3.6 \%)$ \\
Tramadol. & $5(0.15 \%)$ \\
THC. & $1(0.03 \%)$ \\
Morphine. & Benzo.
\end{tabular}


Table 4: Prevalence of the mainly found drug abuse in different age groups

\begin{tabular}{|c|c|c|l|l|l|l|}
\hline & \multicolumn{5}{|c|}{ Age groups } & \multirow{2}{*}{ P value } \\
\cline { 2 - 7 } & $\begin{array}{c}<18 \\
(\mathrm{n}=17)\end{array}$ & $\begin{array}{l}18-30 \\
(\mathrm{n}=1262)\end{array}$ & $\begin{array}{l}30-40 \\
(\mathrm{n}=1218)\end{array}$ & $\begin{array}{l}40-50 \\
(\mathrm{n}=580)\end{array}$ & $\begin{array}{l}>50 \\
(\mathrm{n}=261)\end{array}$ & \\
\hline+ Ve cases & $2(11.8 \%)$ & $\begin{array}{c}251 \\
(19.9 \%)\end{array}$ & $170(14 \%)$ & $44(7.6 \%)$ & $6(2.3 \%)$ & $<0.001^{*}$ \\
\hline Tramadol & $2(11.8 \%)$ & $\begin{array}{c}193 \\
(15.3 \%)\end{array}$ & $126(10.3 \%)$ & $21(3.6 \%)$ & $5(1.9 \%)$ & $<0.001^{*}$ \\
\hline THC & $0(0 \%)$ & $106(8.4 \%)$ & $88(7.2 \%)$ & $27(4.7 \%)$ & $1(0.4 \%)$ & $<0.001^{*}$ \\
\hline Morphine & $0(0 \%)$ & $5(0.4 \%)$ & $6(0.5 \%)$ & $3(0.5 \%)$ & $0(0 \%)$ & 0.831 \\
\hline Benzo & $0(0 \%)$ & $1(0.1 \%)$ & $0(0 \%)$ & $1(0.2 \%)$ & $0(0 \%)$ & 0.699 \\
\hline
\end{tabular}


Table 5: Drug of abuse in relation to driver's vehicle type

\begin{tabular}{|l|l|l|c|}
\hline & $\begin{array}{l}\mathbf{V e} \\
(\mathbf{n = 2 8 6 5})\end{array}$ & $\begin{array}{l}\mathbf{+ V e} \\
(\mathbf{n}=\mathbf{4 7 3})\end{array}$ & P value \\
\hline $\begin{array}{l}\text { Vehicle type: } \\
\text { Private car }\end{array}$ & $482(16.8 \%)$ & $77(16.3 \%)$ & 0.921 \\
$\begin{array}{l}\text { Taxi \& microbus } \\
\text { Truck }\end{array}$ & $\begin{array}{l}2070(72.3 \%) \\
313(10.9 \%)\end{array}$ & $\begin{array}{l}546(73.2 \%) \\
50(10.5 \%)\end{array}$ & \\
\hline
\end{tabular}

Table 6: Prevalence of drug abuse by month

\begin{tabular}{|l|l|l|l|}
\hline Month & $\begin{array}{l}- \text { Ve } \\
(\mathbf{n = 2 8 6 5})\end{array}$ & $\begin{array}{l}\text { +Ve } \\
(\mathbf{n = 4 7 3})\end{array}$ & P value \\
\hline September. & $225(7.9 \%)$ & $117(24.7 \%)$ & \\
October. & $382(13.3 \%)$ & $108(22.8 \%)$ & \\
November. & $633(22.1 \%)$ & $88(18.6 \%)$ & $<0.001^{*}$ \\
December. & $786(27.4 \%)$ & $88(18.6 \%)$ & \\
January. & $750(26.2 \%)$ & $55(11.6 \%)$ & \\
February. & $89(3.1 \%)$ & $17(3.6 \%)$ & \\
\hline
\end{tabular}




\section{DISCUSSION}

In the present study, our results revealed that $14.2 \%$ of the drivers in Minia governorate are drug abusers. The age group (18-30) years showed the highest percentage of drug abuse. This is a terrible sign because this age group is the most energetic and creative age group in the community. This is in agreement with Hamdi et al. (2016) who revealed that the adult age group (20.8 \pm 8.1 years old $)$ had a high percentage of drug abuse in a community survey among Egyptians from 8 governorates.

Moreover, a study was done in America in 2013 found that high age of drug abuse (about 30\%) in young adults (Johnston et al., 2016). A previous research on drivers in Luxembourg proved that the higher age group of drug abusers was at (1825 years old) (Appenzeller et al., 2005). Alti and Aliyu (2008) found that $55.5 \%$ of the drivers in Zaria under drug abuse were in the age group 21-25 years. The mean age of onset of substance use is 20.8 years $(\mathrm{SD}=8.1$ years $)$.

While, these results are incomparable to those reported by Mageid (2017) to 427 drivers admitted to Alexandria Main University Hospital after road traffic accidents. They revealed that the highest age group was 35-45 years old. This difference may be due to wide variation and large number of drivers used in our study. Hamdi et al. (2013) have reported that the incidence of substance abuse is different up to 3-fold among governorates. Yunusa et al., (2017) revealed that the age range of 25-34 years of the commercial bus drivers are more subjected to drug abuse.

The results of this study showed that Tramadol was the most common drug of abuse among drivers in Minia Governorate followed by THC then morphine and finally benzodiazepine. This may be attributed to widespread of tramadol that is marketed with many brand names all over the world (Wolfe et al., 2009). 
Moreover, it is easily gained with cheaper price than cannabis. It has been recorded that tramadol has become the preferred entertaining drug in Egypt, replacing cannabis and hashish (The Economist, 2015). Tramadol is a central analgesic that is used to relieve moderate and severe pain. It is metabolized to desmetramadol, which is an extra powerful opioid (Raffa et al., 2012). In contrast to opioids, tramadol has lower risk to give rise to drug abuse and dependence (Ferrari et al., 2014).

Our findings corroborates those of Yunusa et al., (2017) who reported that the commercial bus drivers subjected to drug abuse with low-price and easily obtained to them such as tramadol. In 2013, it has been reported that the young adults (aged 18-25 years old) have the uppermost rate of tramadol abuse for nonmedical purposes (Babalonis et al., 2013).

The present results are at variance to Aglan and Adawi (2016) who reported that cannabis is the most common abused drug among the cab-drivers followed by tramadol. They attributed that to the widespread of Hashish in Egypt. Furthermore, they reported that the commonness of substance abuse such as alcohols, cocaine and marijuana differs among countries and even among continents. Assari et al. (2014) recorded that opioids are the most frequently abused drug among the Iranian drivers followed by cannabis.

Our study revealed that the combination of tramadol and cannabis has higher prevalence than other combinations. It has been reported that Injury Severity Score (ISS) was significantly higher with consumption of both cannabis and tramadol, due to their synergistic effect which alter the brain functions and inconsequence increase the risk of the road accidents (Mageid, 2017). A previous research on trauma Egyptian patients found that the prevalence of the road accidents increased with tramadol overdose 
(Fawzi, 2011). While, other research reported that no relation between the prevalence of road accidents and cannabis abuse (Mura et al., 2003).

The current study showed an insignificant difference among drivers of different types of vehicle in relation to drug abuse. Girotto et al. (2014) reported that the truck drivers are the commonly drug abusers while the incidence differs from place to another and dependent on methodology employed. In addition, there was a positive correlation between the drug abuse and the poor driving conditions such as driving for hours.

The majority of Egyptian drivers are of middle or low educational level (Mageid, 2017). Moreover, driving for a long distance with the need to work hard without fatigue and stress to gain more income is the main cause to engage in substance abuse (Alti and Aliyu, 2008). Hence, education interest and increase of awareness is needed to decrease engagement in drug abuse even though there is an insignificant relation to cause road accidents (Derakhshanfar et al., 2012).

Consistent with the WHO, the prevalence of the road traffic accidents increases with alcohol (above $0.04 \mathrm{~g} / \mathrm{dl}$ BAC) and drug abuse about five times higher than with the non-abusers because they alter drivers` perception, motor skills and the ability to control situations. WHO has revealed that the fatality rate of road accidents in Egypt is 42 deaths per 100,000 residents (WHO, 2009).

\section{In Egypt, Aglan and Adawi} (2016) has reported that $53.3 \%$ of cab-drivers involved in road accidents were under substance abuse. Hamdi et al. (2013) have demonstrated that alcohol abuse became the second most common drug abuse while its incidence (2.2\%) is still lower than other countries. 


\section{CONCLUSION}

The present study concluded that $14.2 \%$ of the drivers in Minia governorate are under drug of abuse. Tramadol is the most common drug of abuse among drivers in Minia Governorate. Age group (18-30 years old) is the highest percentage of drug abuse.

\section{RECOMMENDATIONS}

Further studies are required to detect the relation between drug abuse and the incidence of road traffic accidents.

\section{Funding}

No funds have been received for this study.

\section{Conflict of interest}

There is no conflict of interest between authors.

\section{REFERENCES}

Aglan, M. and Adawi A. (2016): Incidence of Substance Abuse among Cab-drivers Involved in
Non Fatal Accidents. Trends in Medical Research, 11 (1): 20-27. Alti, M.M. and Aliyu, A.A. (2008): Prevalence of psychoactive substance use among commercial motorcyclists and its health and social consequences in Zaria, Nigeria. Ann Afr Med, 7(2):6771.

Andrade, S.S. and Mello-Jorge, M.H. (2016): Mortality and potential years of life lost by road traffic injuries in Brazil, 2013. Rev Saude Publica, 50:59.

Appenzeller, B.M.; Schneider, S.; Yegles, M.; Maul, A. and Wennig, R. (2005): Drugs and chronic alcohol abuse in drivers. Forensic Sci Int, 155:83-90.

Asbridge, M. (2014): Driving after marijuana use: the changing face of "impaired" driving. JAMA Pediatr, 168:602-604.

\section{Assari, $\quad$ S.; Lankarani,} M.M.; Dejman, M.; Farnia, M.; Alasvand, R.; Sehat, M. and et al. (2014): Drug Use among Iranian Drivers Involved 
in Fatal Car Accidents. Front Psychiatry, 5: 69.

Babalonis, S.; Lofwall, M.R.; Nuzzo, P.A.; Siegel, A.J. and Walsh, S.L. (2013): Abuse Liability and Reinforcing Efficacy of Oral Tramadol in Humans. Drug Alcohol Depend, 129(1-2): 116-124.

Calafat, A.; Blay, N.; Juan, M.; Ad rover, D.; Bellis, M.A.; Hughes, K. and et al. (2009): Traffic risk behaviors at nightlife: Drinking, taking drugs, driving and use of public transport by young people. Traffic Injury Prev., 10: 162-169. Derakhshanfar, H.; Meibodi, M.K.; Kariman, H.; Arhamidolatabadi, A. and Safari, S. (2102): Substance Abuse among Drivers of Motor Vehicle Collisions. Trauma Mon, 17(1):236-238.

Ekpenyong, S.N. (2012): Drug Abuse in Nigerian Schools: A Study of Selected Secondary Institutions in Bayelsa State, South-South, Nigeria. International Journal of Scientific
Research in Education, 5(3): 260268.

El-Akabawi A. Drug abuse in the Arab world: a country profile Egypt. In: Okasha A, Maj M, editors. Images in psychiatry: an Arab perspective: WPA series, Scientifc Book House for Publishing and Distributing 2001; 143- 150.

El-Gendy，S.D.; El-Gendy，M.F.; Dawah, A.Y.; Eldesouky, R.S. and El-Raof, M.S. (2015): Risky road-use behaviour among students at the University of Benha, Egypt. East Mediterr Health J, 21:120-8.

El-Sawy, H.; Abdel Hay, M. and Badawy, A. (2010): Gender Differences in Risks and Pattern of Drug Abuse in Egypt. Egypt J Neurol Psychiat Neurosurg, 47(3): 413-418.

Fawzi, M. (2011): Some medicolegal aspects concerning tramadol abuse: The new Middle East youth plague 2010. An Egyptian overview. Egyptian Journal of Forensic Sciences, 1:99-102. 
Ferrari, A.; Tiraferri, I.; Palazzoli,

F. and Licata, M. (2014):

Tramadol Abuse in a Binge

Pattern in a Young Depressed

Woman. Eur Addict Res, 20:8286.

Girotto, E.; Mesas, A.E.; De Andrade, S.M. and Birolim, M.M. (2014): Psychoactive substance use by truck drivers: A systematic review. Occup. Environ. Med, 71: 71-76.

Hamdi, E.; Gawad, T.; Khoweiled, A.; Sidrak, A. and Amer, D. (2013): Lifetime prevalence of alcohol and substance use in Egypt: a community survey. Subst Abus, 34:97-104.

Hamdi, E.; Sabry, N.; Sedrak, A. and Khowailed, A.N.L. (2016): Sociodemographic Indicators for Substance Use and Abuse in Egypt. J Addiction Prevention, 4:1-8.

Johnston, L.; O’Malley, P.; Miech, R.A.; Bachman, J.G. and Schulenberg, J.E. Monitoring the Future national survey results on drug use, 1975
2015:Overview, key findings on adolescent drug use. Ann Arbor: Institute for Social Research, The University of Michigan 2016; 111.

Kenntner-Mabiala, R.; Kaussner, Y.; Jagiellowicz-Kaufmann, M.; Hoffmann, S. and Kruger, H.P. (2015): Driving performance under alcohol in simulated representative driving tasks: an alcohol calibration study for impairments related to medicinal drugs. J Clin Psychopharmacol, 35:134-142.

Lillsunde, P.; Langel, K.; Blencowe, T.; Kivioja, A.; Karjalainen, $\quad \mathrm{K}$.; $\quad$ and Lehtonen, $\quad$ L. (2012): Psychoactive drugs and accident risk in road traffic. Duodecim, 128: $1877-1886$.

Loffredo, C.A.; Boulos, D.N.; Saleh, D.A.; Jillson, I.A.; Garas, M. and Loza, N. (2015): Substance use by Egyptian youth: current patterns and potential avenues for prevention. Subst Use Misuse, 50:609-618. 
Mageid, R.A. (2017): Estimation of the Prevalence of Tramadol and Cannabis Abuse among Drivers Involved in Road Traffic Accidents Admitted to Alexandria Main University Hospital: A Prospective Study. International Journal of Contemporary Medical Research, 4(4):848-852.

McCree,

D.H.; Cosgrove,

S.; Stratford, D.; Valway, S.; Keller, N.; Vega-Hernandez, J. and Jenison, S.A. (2010): Sexual and drug use risk behaviors of long-haul truck drivers and their commercial sex contacts in New Mexico. Public Health Rep., 125: 52-60.

Mura, P.; Kintz, P.; Ludes, B.; Gaulier, J.; Marquet, P. and Martin- Dupont, S. (2003): Comparison of the prevalence of alcohol, cannabis and other drugs between 900 injured drivers and 900 control subjects: results of a French collaborative study. Forensic science international, 133:79-85.
Nutt, D.; King, L.A.; Saulsbury, W. and Blakemore, C. Development of a rational scale to assess the harm of drugs of potential misuse. The Lancet 2010; 1047-1053.

Raffa. R.B.; Buschmann, H.; Christoph, T.; Eichenbaum, G.; Englberger, W.; Flores, C.M. and et al. (2012): Mechanistic and functional differentiation of tapentadol and tramadol. Expert Opin Pharmacother. 13 (10): 1437-49.

Smook, B.; Ubbink, M.; Ryke, E. and Strydom, H. (2014): Substance abuse, dependence and the workplace: A literature overview. Social Work Journal, 50(1).

DOI: http://dx.doi.org/10.15270/50-1$\underline{16}$.

The Economist (2015): Drug abuse in Egypt - A pill for work and play.

www.economist.com/news/middl e-east-and-africa/21648690painkiller-becomes-egypts- 
favourite-recreational-drug-pill-

work-and-play

Verstraete, A.G. and Legrand, S. Methodological issues in determining the relationship between drug consumption, impaired driving and traffic accidents. In, Drug use, impaired driving and traffic accidents, $2^{\text {nd }}$ ed. European Monitoring Centre for Drugs and Drug Addiction, Spain 2014, 13-27.

Wolfe, S.M.; Sasich, L.D.; Hope, R.E.; Knapp, D.E. and Shubin, S. Drugs for pain and arthritis. In, Worst bills, best bills. Avenue of the Americas, New York, NY 2009.

World Health Organization (WHO), "Road traffic injuries World Health Organization
Regional Office for the Eastern Mediterranean", Geneva, Switzerland 2009.

World Health Organization (WHO), "Global Status Report on Road Safety". Geneva: World Health Organization 2013.

World Health Organization (WHO), "Global Status Report on Road Safety". Geneva: World Health Organization 2015.

Yunusa, U.; Bello, U.L.; Idris, M.; Haddad, M.M. and Adamu, D. (2017): Determinants of Substance Abuse among Commercial Bus Drivers in Kano Metropolis, Kano State, Nigeria. American Journal of Nursing Science, 6(2): 125-130. 


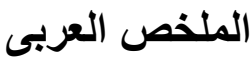

في مصر ، يعتبر تعاطي المخدرات إحدى المشاكل الخطيرة التي تهدد الثباب وتقلق الحكومة.

و أحد أهم النقاط الأساسية لمتعاطي المخدرات هم أولئك الذين يتعاملون مع النقل و القيادة على الطريق لأن

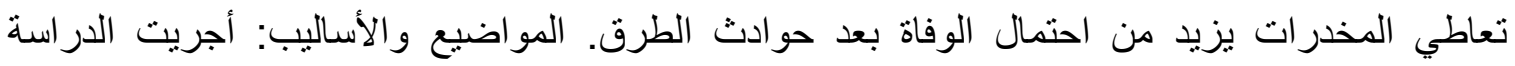
بمحافظة المنيا من أجل تحديد مدى انتثار تعاطي المخدرات في عينات البول من السائقين. تم إجراء اختبار الفصص بالتعاون مع وزارة الصحة ووزارة الداخلية. أجريت الدراسة في محافظة المنيا من 6 سبتمبر 2014 حتى 5 فبر اير 2015 على 3338 سائق ذكر نتراوح أعمار هم بين (16-70) سنة. النتائج: كان الاختبار إيجابيا في 473 سائق (14.2 \%). لوحظت أعلى نسبة من تعاطي الدخدرات بين الفئة العمرية (18-18) سنة. كان انتشار الترامادول 7.2 ٪ ، 3.6 ٪ الحشيش المخدر، الأفيون 0.15 \% ، البنزوديازييينات 0.03 ٪ ، ترامادول مجتمعة و الحشيش 2.9 ٪ ، الترامادول و الأفيون 0.1 ٪ ، ترامادول و البنزوديازييينات 0.03 ٪ ، الحشيش و الأفيون 0.2 ٪ . وفقا لنوع السيارة ؛ كان سائقي سيارات الأجرة و الميكروباص أعلى نسبة فى تعاطي المخدرات تليها السيار ات الخاصة ثم سائقي الثشاحنات. هناك انخفاض في عدد الحالات الإيجابية بين فترة الدراسة من سبتمبر حتى فبراير. الخلاصة: أعلى نسبة من تعاطي المخدرات هي بين الفئة العمرية (18-30) سنة. يعتبر ترامادول أكثر الأنواع شيوعا بين السائقين في

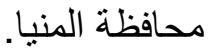

